\title{
Pengembangan Media Pembelajaran Berbasis Web Untuk Matakuliah Kurikulum dan Pengajaran di Jurusan Pendidikan Teknik Informatika Universitas Pendidikan Ganesha
}

\author{
Dewa Gede Hendra Divayana \\ Pendidikan Teknik Informatika \\ Universitas Pendidikan Ganesha \\ Singaraja, Indonesia
}

\author{
P. Wayan Arta Suyasa ${ }^{2}$ \\ Pendidikan Teknik Informatika \\ Universitas Pendidikan Ganesha \\ Singaraja, Indonesia
}

\author{
Nyoman Sugihartini ${ }^{3}$ \\ Pendidikan Teknik Informatika \\ Universitas Pendidikan Ganesha \\ Singaraja, Indonesia
}

\begin{abstract}
Perkembangan teknologi informasi dan komunikasi kini telah mengubah cara pandang dan bertindak masyarakat dalam menghabiskan waktu untuk bekerja dan mengatasi segala permasalahannya. Bentuk-bentuk perkembangan dan perubahan teknologi informasi pada dasarnya merubah aktifitas masyarakat dalam dunia nyata ke dalam aktifitas dunia maya. Banyak lagi bentuk perubahan lainnya terjadi dalam sendi-sendi kehidupan masyarakat yang dibawa oleh perkembangan dan kemajuan TI, tidak terkecuali, dalam dunia pendidikan. Dampak kemajuan TIK dalam dunia pendidikan sangatlah luar biasa. Berbagai model pembelajaran dengan memanfaatkan komputer seperti: e-learning (electronic learning), Computer Assisted Instruction (CAI), Computer Based Instruction (CBI), dan e-teaching (electronic teaching) sangat memungkinkan memfasilitasi perkembangan dunia pendidikan. Model pembelajaran tersebut memungkinkan pendidik dan peserta didik mencari bahan pembelajaran sendiri langsung dari situs-situs di internet melalui komputer sebagai sarana belajar. Kurikulum dan Pengajaran merupakan salah satu matakuliah wajib pada Jurusan Pendidikan Teknik Informatika. Berdasarkan kurikulum 2012, matakuliah tersebut diperoleh pada semester 3 (mahasiswa reguler) dan semester 1 (mahasiswa alih kredit). Salah satu model kurikulum yang dipelajari dalam matakuliah tersebut yaitu kurikulum tingkat satuan pendidikan (KTSP) dan kurikulum 2013. Berdasarkan pembelajaran kurikulum tingkat satuan pendidikan (KTSP) dan kurikulum 2013 sebelumnya, diidentifikasi beberapa permasalahan yaitu kurangnya minat dan perhatian mahasiswa pada mata kuliah kurikulum, sehingga diperlukan suatu metode atau media yang kreatif yang diharapkan dapat meningkatkan minat dan motivasi belajar mahasiswa pada mata kuliah kurikulum dan pengajaran. Adapun media pembelajaran yang dikembangkan yaitu media pembelajaran berbasis web untuk matakuliah Kurikulum dan Pengajaran. Desain pengembangan yang digunakan dalam mengembangkan media pembelajaran berbasis web untuk matakuliah Kurikulum dan Pengajaran ini yaitu dengan desain pengembangan model Dick \& Carey.
\end{abstract}

Keywords-Media Pembelajaran, Kurikulum dan Pengajaran, KTSP, Kurikulum 2013

\section{PENDAHULUAN}

Dampak kemajuan teknologi informasi dan komunikasi kini telah mengubah cara pandang dan bertindak masyarakat dalam menghabiskan waktu untuk bekerja dan mengatasi segala permasalahannya. Bentuk-bentuk perkembangan dan perubahan teknologi informasi pada dasarnya merubah aktifitas masyarakat dalam dunia nyata ke dalam aktifitas dunia maya. Banyak lagi bentuk perubahan lainnya terjadi dalam sendisendi kehidupan masyarakat yang dibawa oleh perkembangan dan kemajuan TI, tidak terkecuali, dalam dunia pendidikan. Dampak kemajuan TIK dalam dunia pendidikan sangatlah luar biasa. Berbagai model pembelajaran dengan memanfaatkan komputer seperti: e-learning (electronic learning), Computer Assisted Instruction (CAI), Computer Based Instruction (CBI), dan e-teaching (electronic teaching) sangat memungkinkan memfasilitasi perkembangan dunia pendidikan. Model pembelajaran tersebut memungkinkan pendidik dan peserta didik mencari bahan pembelajaran sendiri langsung dari situssitus di internet melalui komputer sebagai sarana belajar.

Dengan demikian dunia pendidikan termasuk yang sangat diuntungkan dari kemajuan TIK karena memperoleh manfaat yang luar biasa baik dari segi model pembelajaran maupun pemanfaatan media-media pembelajaran. Pemanfaatan media pembelajaran berbasis komputer dinilai lebih optimal digunakan dalam menunjang pendidikan saat ini karena dengan media pembelajaran peserta didik dapat belajar dan menganalisis sendiri materi ajar kapanpun dan dimanapun mereka berada tanpa harus menunggu kehadiran pendidik untuk menjelaskan materi ajar tersebut.

Kurikulum dan Pengajaran merupakan salah satu matakuliah wajib pada Jurusan Pendidikan Teknik Informatika, Fakultas Teknik dan Kejuruan, Universitas Pendidikan Ganesha. Materi yang diberikan pada pembelajaran tersebut melingkupi tentang mengkaji aspek teoritis dan praktis yang berkaitan dengan kurikulum dan pengajaran. Salah satu model kurikulum yang dipelajari yaitu kurikulum tingkat satuan 
pendidikan (KTSP) dan kurikulum 2013. Berdasarkan pembelajaran kurikulum tingkat satuan pendidikan (KTSP) dan kurikulum 2013 sebelumnya, diidentifikasi beberapa permasalahan yaitu kurangnya minat dan perhatian mahasiswa pada mata kuliah kurikulum, sehingga diperlukan suatu metode atau media kreatif yang diharapkan dapat meningkatkan minat dan motivasi belajar mahasiswa pada mata kuliah kurikulum dan pengajaran. Kenyataannya, pembelajaran mata kuliah kurikulum dan pengajaran yang dilakukan oleh dosen masih berupa pembelajaran konvensional. Akibatnya, hasil belajar mahasiswa tidak sesuai dengan harapan. Hal tersebut dibuktikan dengan data yang diperoleh dari nilai semester ganjil mahasiswa tahun akademik 2013/2014, rata-rata nilai akhir untuk mata kuliah kurikulum dan pengajaran masih tergolong cukup dan belum menunjukkan kategori baik (Arsip nilai akhir semester ganjil tahun akademik 2013/2014, jurusan PTI, Undiksha).

Pemilihan model dan metode pembelajaran yang sesuai dengan tujuan kurikulum dan potensi mahasiswa merupakan kemampuan dan keterampilan dasar yang harus dimiliki oleh seorang dosen. Hal ini didasari asumsi bahwa ketepatan dosen dalam memilih model dan metode pembelajaran akan berpengaruh terhadap keberhasilan dan hasil belajar mahasiswa. Karena model dan metode pembelajaran yang digunakan oleh dosen berpengaruh terhadap kualitas proses belajar mengajar yang dilakukannya. Kondisi proses belajar mengajar di lingkungan kampus dewasa ini masih diwarnai oleh penekanan pada aspek pengetahuan dan masih sedikit yang mengacu pada pelibatan mahasiswa dalam proses belajar itu sendiri. Pembelajaran mata kuliah kurikulum dan pengajaran yang dilakukan oleh dosen belum mampu menumbuhkan budaya belajar mahasiswa. Hal ini akan berpengaruh secara langsung terhadap perolehan dan hasil belajar mahasiswa. Melihat permasalahan tersebut, maka isu yang sering diangkat oleh media masa cetak maupun elektronik tentang rendahnya mutu pendidikan kita dewasa ini secara kualitatif diduga disebabkan karena model pembelajaran yang dianut oleh dosen didasarkan atas asumsi tersembunyi bahwa pembelajaran mata kuliah kurikulum dan pengajaran adalah suatu pengetahuan yang bisa dipindahkan secara utuh dari pikiran dosen ke pikiran mahasiswa (Lasmawan, 2002).

Dosen sebagai mediator dan manajer pembelajaran harus mampu menjadikan pembelajaran yang dikembangkannya "menyenangkan dan menggugah" peserta didik untuk belajar. Karena pembelajaran yang bermakna adalah bilamana pembelajaran tersebut mampu "menjadikan" peserta pembelajaran merasa nyaman, enjoy, termotivasi, dan tertantang untuk belajar, belajar, dan belajar. Pada konteks ini, seorang dosen harus mampu melakukan berbagai variasi pembelajaran, sesuai dengan karakteristik materi, kebutuhan belajar peserta didik, lingkungan belajar, dan target capaian dari pembelajaran itu sendiri. Untuk itu, salah satu keterampilan professional yang "sebaiknya" dimiliki oleh seorang dosen adalah keterampilan inovatif. Pembelajaran inovatif adalah pembelajaran yang lebih bersifat student centered. Artinya, pembelajaran yang memberikan peluang kepada mahasiswa untuk mengkonstruksi pengetahuan secara mandiri (self directed) dan dimediasi oleh teman sebaya (peer mediated instruction). Pembelajaran inovatif mendasarkan diri pada paradigma konstruktivistik (Kertih, 2006).

Masalah utama dalam pembelajaran kurikulum dan pengajaran ialah penggunaan metode atau model pembelajaran dalam menyampaikan materi pelajaran secara tepat, yang memenuhi muatan tatanan nilai, agar dapat diinternalisasikan pada diri mahasiswa serta mengimplementasikan hakikat pendidikan nilai dalam kehidupan sehari-hari belum memenuhi harapan seperti yang diinginkan. Hal ini berkaitan dengan kritik masyarakat terhadap materi pembelajaran kurikulum dan pengajaran yang tidak bermuatan nilai-nilai praktis tetapi hanya bersifat teori atau hafalan belaka untuk kepentingan memperoleh nilai atau IPK yang tinggi. Metode pembelajaran dalam proses belajar mengajar (PBM) terkesan sangat kaku, kurang fleksibel, kurang demokratis, dan dosen cenderung lebih dominan one way method. (Lasmawan, 2006).

Untuk menghadapi kritik masyarakat tersebut di atas, ada suatu media pembelajaran yang efektif dan efisien sebagai alternatif, yaitu dengan menggunakan web sebagai media pembelajaran. Tidak dapat dipungkiri keberadaan media pembelajaran berbasis komputer telah menjadi bagian penting dalam dunia pendidikan saat ini. Media berbasis komputer dalam pengembangan media pembelajaran sering kali disebut dengan multimedia pembelajaran karena kemampuan media komputer dalam menyampaikan pesan melalui media visual, media audio, text baik berupa rekaman atau berupa media siaran. Teknologi ini diharapkan akan dapat membantu proses pendidikan secara umum maupun khusus sehingga apa yang ingin dicapai melalui proses pendidikan dapat diperoleh dengan baik. Walaupun masih dapat diperdebatkan, peran prinsip dari teknologi ini adalah untuk membantu peningkatan efisiensi proses belajar mengajar secara keseluruhan (Darmawan, 2006). Sunarya (2012) melakukan kajian tentang penggunaan teknologi komputer animasi dalam pembelajaran Komunikasi Data dan Jaringan Komputer. Mahendra (2014) mengembangkan media pembelajaran berbasis simulasi untuk pembelajaran perakitan komputer dan instalasi sistem operasi.

Berdasarkan permasalahan dan penelitian-penelitian yang telah dilakukan sebelumnya, maka akan dikembangkan sebuah media pembelajaran berbasis web untuk matakuliah Kurikulum dan Pengajaran dengan studi kasus pada Jurusan Pendidikan Teknik Informatika, Universitas Pendidikan Ganesha.

\section{KAJIAN PUSTAKA}

A. Media Pembelajaran

1. Definisi Media Pembelajaran

Media merupakan apa saja yang mengantarkan atau membawa informasi ke penerima informasi. Di dalam proses belajar mengajar yang pada hakikatnya juga merupakan proses komunikasi. Informasi atau pesan yang 
dikomunikasikan adalah isi atau bahan ajar yang telah ditetapkan dalam kurikulum. Sumber informasi adalah guru, penulis buku, perancang dan pembuat media pembelajaran lainnya, sedangkan penerima informasi adalah siswa atau warga belajar (Suherman, 2009).

Media berasal dari bahasa latin merupakan bentuk jamak dari "Medium" yang secara harfiah berarti "Perantara" atau "Pengantar" yaitu perantara atau pengantar sumber pesan dengan penerima pesan (Darmawiguna dan Kesiman, 2013).

Media merupakan alat untuk menyampaikan informasi atau pesan dari suatu tempat ke tempat lain. Media digunakan dalam proses komunikasi, termasuk kegiatan belajar mengajar. Proses pembelajaran mengandung lima komponen komunikasi, yakni guru (komunikator), bahan pembelajaran, media pembelajaran, siswa (komunikan), dan tujuan pembelajaran (Santyasa, 2007).

Salah satu cara yang dapat digunakan untuk meningkatkan efektifitas dari proses pembelajaran adalah dengan membangun media pembelajaran interaktif (Amalia, Ambarsari, dan Wigoyo, 2014).

Dari beberapa pendapat diatas maka dapat diambil kesimpulan umum bahwa media pembelajaran adalah segala sesuatu yang dapat digunakan untuk menyalurkan pesan (bahan pembelajaran), sehingga dapat merangsang perhatian, minat, pikiran, dan perasaan siswa dalam kegiatan belajar untuk mencapai tujuan belajar.

2. Jenis-jenis Media Pembelajaran

Terdapat enam jenis dasar dari media pembelajaran menurut Heinich dan Molenda (2005) yaitu:

a. Teks

Merupakan elemen dasar bagi menyampaikan suatu informasi yang mempunyai berbagai jenis dan bentuk tulisan yang berupaya memberi daya tarik dalam penyampaian informasi.

b. Media Audio

Membantu menyampaikan materi dengan lebih berkesan membantu meningkatkan daya tarikan terhadap suatu persembahan. Jenis audio termasuk suara latar, musik, atau rekaman suara dan lainnya.

c. Media Visual

Media yang dapat memberikan rangsanganrangsangan visual seperti gambar/foto, sketsa, diagram, bagan, grafik, kartun, poster, papan buletin dan lainnya. d. Media Proyeksi Gerak

Termasuk di dalamnya film gerak, film gelang, program TV, kaset video (CD, VCD, atau DVD)

e. Benda-Benda Tiruan/Miniatur

Seperti benda-benda tiga dimensi yang dapat disentuh dan diraba oleh siswa, media ini dibuat untuk mengatasi keterbatasan baik obyek maupun situasi sehingga proses pembelajaran tetap berjalan dengan baik.

\section{f. Manusia}

Termasuk di dalamnya guru, siswa, pakar, ahli di bidang materi tertentu.

\section{B. Kurikulum Tingkat Satuan Pendidikan (KTSP) dan} Kurikulum 2013

1. Pengertian KTSP

Menurut Peraturan Pemerintah Nomor 19 Tahun 2005 Tentang Standar Nasional Pendidikan Bab 1 Pasal 1 Ayat (15) Kurikulum Tingkat Satuan Pendidikan (KTSP) adalah "Kurikulum operasional yang disusun oleh dan dilaksanakan di masing-masing satuan pendidikan." Kurikulum tersebut telah diberlakukan secara berangsungangsur mulai tahun pelajaran 2006/2007, pada jenjang pendidikan dasar dan menengah.

\section{Pengertian Kurikulum 2013}

Kurikulum 2013 adalah kurikulum yang intinya terletak pada upaya penyederhanaan, dan tematikintegratif. Kurikulum 2013 disiapkan untuk mencetak generasi yang siap di dalam menghadapi masa depan. Karena itu kurikulum disusun untuk mengantisipasi perkembangan masa depan. Titik beratnya, bertujuan untuk mendorong peserta didik atau siswa, mampu lebih baik dalam melakukan observasi, bertanya, bernalar, dan mengkomunikasikan(mempresentasikan), apa yang mereka peroleh atau mereka ketahui setelah menerima materi pembelajaran. Adapun obyek yang menjadi pembelajaran dalam penataan dan penyempurnaan kurikulum 2013 menekankan pada fenomena alam, sosial, seni, dan budaya.

C. Web

\section{Definisi Web}

World Wide Web atau WWW atau juga dikenal dengan WEB adalah salah satu layanan yang didapat oleh pemakai computer yang terhubung ke internet. Web ini menyediakan informasi bagi pemakai computer yang terhubung ke internet dari sekedar informasi "sampah" atau informasi yang tidak berguna sama sekali sampai informasi yang serius; dari informasi yang gratisan sampai informasi yang komersial (Dewanto, 2006). Website atau situs dapat diartikan sebagai kumpulan halaman-halaman yang digunakan untuk menampilkan informasi teks, gambar diam atau gerak, animasi, suara, dan atau gabungan dari semuanya itu baik yang bersifat statis maupun dinamis yang membentuk satu rangkaian bangunan yang saling terkait dimana masing-masing dihubungkan dengan jaringan-jaringan halaman (hyperlink).

2. Fungsi Web

Adapun fungsi web secara umum antara lain: fungsi komunikasi, fungsi informasi, fungsi hiburan, fungsi pembelajaran, dan fungsi transaksi. 


\section{METODE PENELITIAN}

\section{A. Objek Penelitian}

Adapun objek dari penelitian ini adalah media pembelajaran berbasis web untuk matakuliah Kurikulum dan Pengajaran.

\section{B. Lokasi Penelitian}

Adapun lokasi penelitian ini dilaksanakan pada jurusan Pendidikan Teknik Informatika, Universitas Pendidikan Ganesha.

\section{Pendekatan Penelitian}

Adapun pendekatan penelitian yang digunakan dalam penelitian ini adalah metode penelitian pengembangan (Research and Development), dengan desain pengembangan yang digunakan adalah model Dick \& Carey.

\section{Teknik Analisis Data}

Data respon mahasiswa, uji ahli dan uji media terhadap produk yang dihasilkan dianalisis dengan menggunakan perhitungan deskriptif persentase. Perhitungan deskriptif persentase menghasilkan persentase penilaian yang selanjutnya digunakan untuk memberikan penafsiran atau penilaian terhadap hasil penelitian dari produk yang dikembangkan.

Adapun rumus yang digunakan untuk perhitungan deskriptif persentase adalah sebagai berikut (Subana dan Sudrajat, 2001).

Persentase $=\frac{\left.\sum \text { (Jawaban } \times \text { Bobot Tiap Pilihan }\right)}{\mathrm{n} \text { xBobot Tertinggi }} \times 100 \%$

Keterangan:

$\sum=$ Jumlah

$\mathrm{n}=$ Jumlah seluruh item angket

Selanjutnya untuk menghitung persentase keseluruhan subjek yang digunakan dengan menggunakan rumus sebagai berikut:

Persentase $=\mathrm{F} / \mathrm{N}$

Keterangan:

$\mathrm{F}=$ Jumlah persentase keseluruhan subjek

$\mathrm{N}$ = banyaknya subjek

\section{HASIL PENELITIAN DAN PEMBAHASAN}

\section{A. Hasil Penelitian}

Data yang telah dikumpulkan dari lapangan yang disesuaikan dengan model Dick \& Carey berikut.

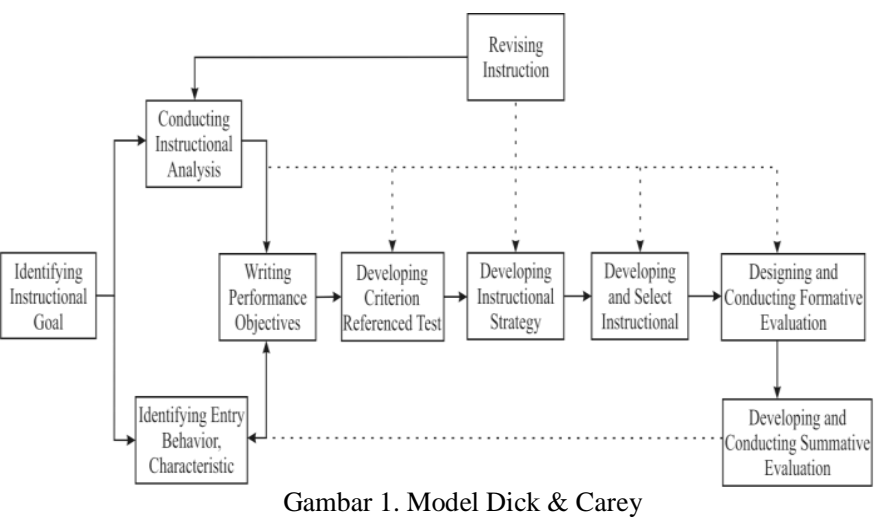

\section{Identifying Instructional Goal}

Pada tahap ini dilakukan proses pengidentifikasian tujuan umum pembelajaran dengan menggunakan analisis kebutuhan.

\section{Conducting Instructional Analysis}

Setelah tahapan pengidentifikasian tujuan umum pembelajaran selesai dilakukan, maka dilanjutkan dengan tahap analisis pembelajaran yaitu sebuah proses yang digunakan untuk menentukan keterampilan dan pengetahuan relevan yang diperlukan oleh mahasiswa untuk mencapai kompetensi yang telah digariskan pada tujuan pembelajaran.

\section{Identifying Entry Behavior, Characteristic}

Pada tahap ini dilakukan pembuatan list keterampilan keterampilan-keterampilan tertentu yang harus dimiliki mahasiswa sebelum pengajaran dimulai.

\section{Writing Performance Objectives}

Hasil yang diperoleh dari tahapan ini yaitu perumusan tujuan khusus yang didasarkan pada hasil analisis pembelajaran terhadap rumusan tujuan umum pembelajaran, serta identifikasi karakteristik dan kemampuan awal mahasiswa.

\section{Developing Criterion-Referenced Test}

Hasil yang diperoleh dari tahapan ini yaitu instrumen tes kognitif yang berbentuk pilihan ganda berdasarkan rumusan tujuan khusus yang telah diperoleh pada tahap sebelumnya.

\section{Developing Instructional Strategy}

Mata kuliah Kurikulum dan Pengajaran ini memiliki alokasi waktu 100 menit yang sesuai dengan silabus yang dikembangkan oleh Jurusan Pendidikan Teknik Informatika, Universitas Pendidikan Ganesha. Mata kuliah ini merupakan mata kuliah teori dan aplikasi dengan sistem pelaksanaan tiap minggu secara berkesinambungan. Dalam mempelajari mata kuliah ini mahasiswa diberikan modul digital yang dapat diakses melalui media pembelajaran berbasis web yang disiapkan oleh pendidik. Keberhasilan penguasaan materi kuliah ini akan tampak pada akhir pembelajaran, yaitu siswa mampu menjawab semua pertanyaan dalam quiz yang tersedia juga dalam media pembelajaran berbasis web tersebut. 


\section{Developing and Selecting Instruction}

Untuk pengembangan media pembelajaran berbasis web tersebut menggunakan metode waterfall. Adapun hasil yang telah diperoleh dari pengembangan media pembelajaran berbasis web menggunakan metode waterfall dapat dijelaskan sebagai berikut.

a. Software Requirements Analysis

Pada tahap ini dilakukan analisis dan penentuan hal-hal fungsional yang dibutuhkan dalam media pembelajaran berbasis web untuk mata kuliah Kurikulum dan Pengajaran, antara lain: fasilitas login admin, login dosen, dan login mahasiswa, pengaturan admin, menampilkan materi, menampilkan soal quiz, dan menampilkan hasil quiz.

\section{b. Design}

Pada tahap ini dilakukan proses untuk mengubah kebutuhan-kebutuhan yang telah dijelaskan pada tahap analisis kebutuhan diatas menjadi representasi ke dalam bentuk "blueprint" software sebelum diimplementasikan. Adapun bentuk design media pembelajaran berbasis web untuk mata kuliah kurikulum dan pengajaran di jurusan Pendidikan Teknik Informatika, Universitas Pendidikan Ganesha dapat dijelaskan sebagai berikut.

1) Design Login Admin dan Pengaturan Admin

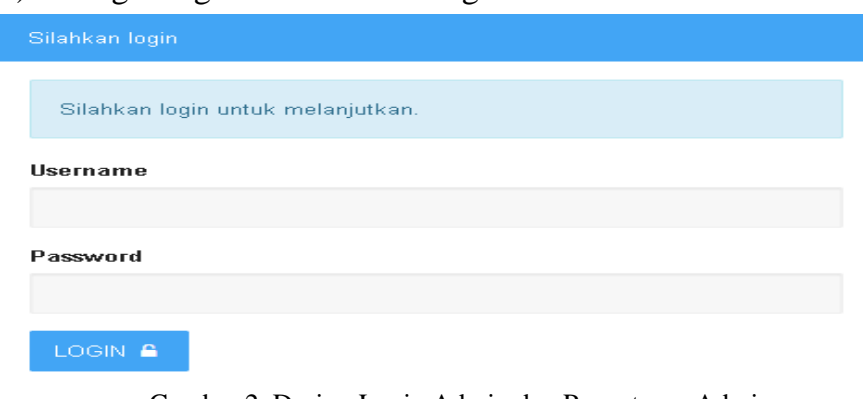

Gambar 2. Design Login Admin dan Pengaturan Admin

Setelah berhasil login admin, maka akan muncul tampilan pengaturan admin berikut.

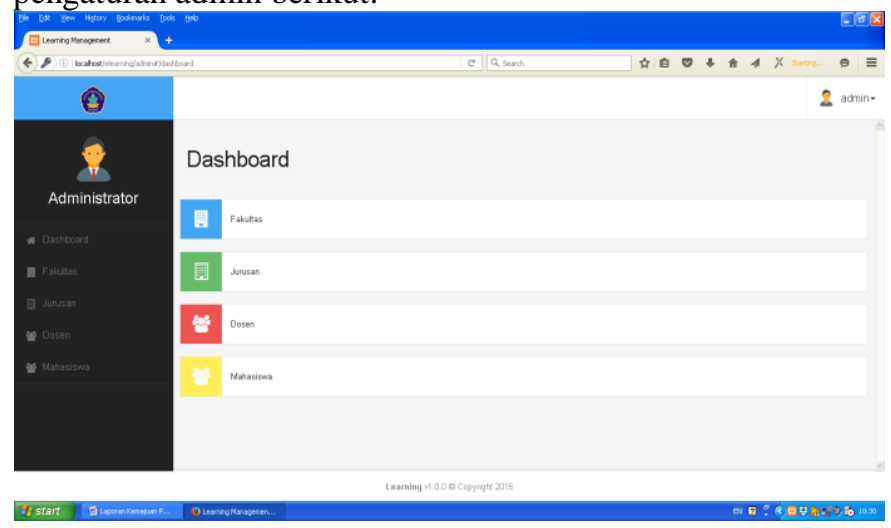

Gambar 3. Design Pengaturan Admin

2) Design Login Dosen/Mahasiswa

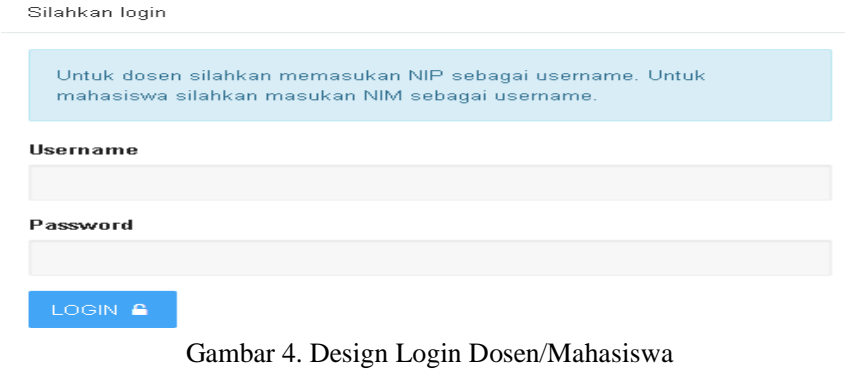

\section{3) Design Tampilkan Materi}

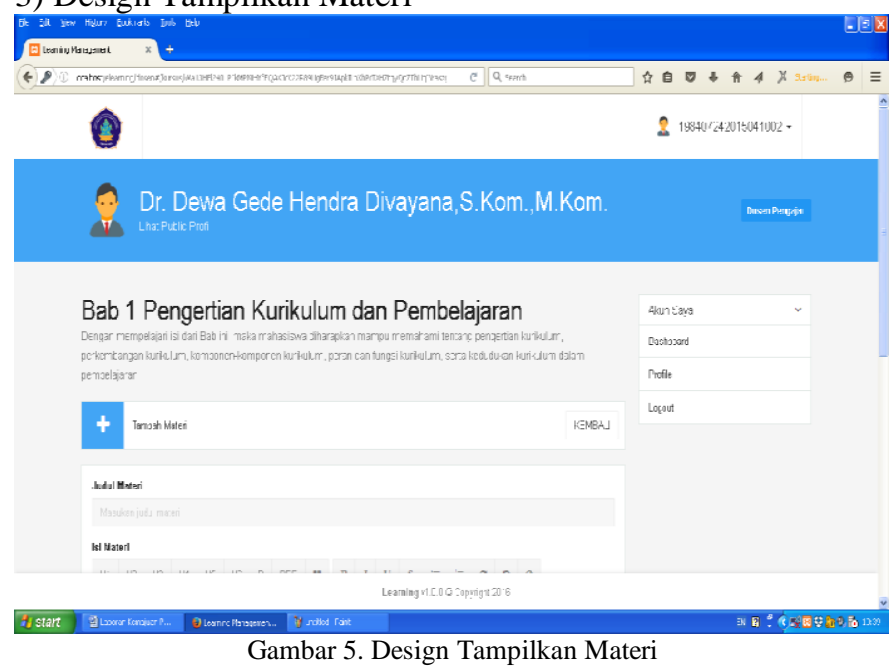

4) Design Tampilkan Soal Quiz

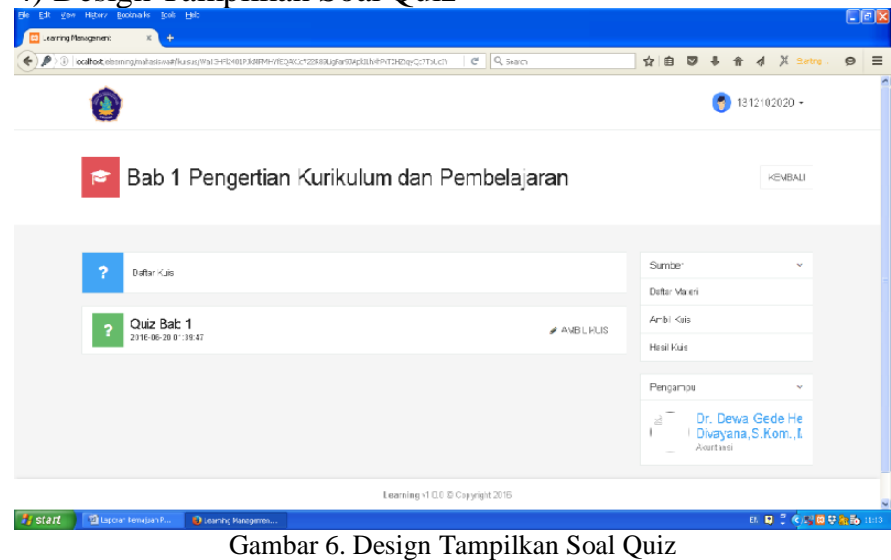

5) Design Melihat Hasil Quiz

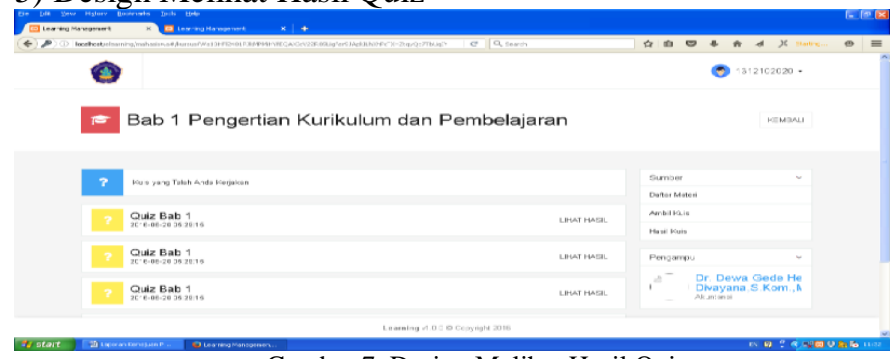

c. Coding 
Agar design yang telah terbentuk sebelumnya dapat dimengerti oleh mesin, dalam hal ini adalah komputer, maka desain tersebut harus dirubah bentuknya menjadi bentuk yang dapat dimengerti oleh mesin, yaitu ke dalam bahasa pemrograman melalui proses pengcodingan.

\section{d. Testing}

Pada tahapan ini dilakukan pengujian terhadap media pembelajaran berbasis web untuk mata kuliah kurikulum dan pengajaran yang dilaksanakan di jurusan Pendidikan Teknik Informatika, Universitas Pendidikan Ganesha. Pengujian dilakukan dengan cara memberikan angket kepada 3 orang mahasiswa dalam uji coba perorangan, 6 orang mahasiswa dalam uji coba kelompok kecil, dan 20 orang mahasiswa dalam uji coba lapangan yang terdiri dari mahasiswa yang telah mengambil mata kuliah Kurikulum dan Pengajaran. Untuk lebih jelasnya tentang data hasil testing terhadap media pembelajaran berbasis web ini dapat dilihat sebagai berikut:

1) Uji Coba Perorangan

Dalam uji coba perorangan ini peneliti menyebarkan angket kepada 3 orang mahasiswa yang mewakili karakteristik mahasiswa yang berkemampuan baik, sedang/menengah, dan yang berkemampuan rendah.

Angket respon siswa ini terdiri dari 10 pernyataan yang terdiri dari 8 butir pernyataan positif yaitu butir 2, 3, 4, 5, 7, 8, 9, 10 dan sebanyak 2 butir pernyataan negatif yaitu butir 1 dan 6. Hasil data kuantitatif dari uji coba perorangan selengkapnya dapat dilihat pada Tabel I dan Tabel II berikut ini.

Tabel I. Angket Dalam Uji Coba Perorangan

\begin{tabular}{|c|c|c|c|c|c|c|c|c|c|c|c|}
\hline \multirow{2}{*}{ Ne } & \multirow{2}{*}{ Responden } & \multicolumn{10}{|c|}{ Nomor Butir } \\
\hline & & $\mathbf{1}$ & 2 & 3 & 4 & 5 & 6 & 7 & $\mathbf{8}$ & 9 & 10 \\
\hline 1 & I & $\mathbf{T S}$ & $\mathbf{s s}$ & $\mathbf{s}$ & SS & SS & TS & SS & $\mathbf{S S}$ & SS & SS \\
\hline 2 & II & TS & Ss & $\mathbf{s}$ & Ss & $\mathbf{s}$ & KS & $\mathbf{s}$ & $\mathbf{s}$ & Ss & $\mathbf{s}$ \\
\hline 3 & III & KS & s & $\mathbf{s}$ & SS & $\mathbf{s}$ & KS & $\mathbf{s}$ & $\mathbf{s}$ & $\mathbf{s}$ & $\mathrm{s}$ \\
\hline
\end{tabular}

Tabel II. Angket Dalam Uji Coba Perorangan Dikali Bobot Tiap Pilihan

\begin{tabular}{|c|c|c|c|c|c|c|c|c|c|c|c|c|c|c|}
\hline \multirow{2}{*}{ No } & \multirow{2}{*}{ Responder } & \multicolumn{10}{|c|}{ Jarrban x Bebot Tinp Priton } & \multirow{2}{*}{ Jabh } & \multirow{2}{*}{ Fresentase } & \multirow{2}{*}{ Kriterin } \\
\hline & & 1 & 2 & 3 & 4 & 5 & 6 & 7 & 8 & 9 & 10 & & & \\
\hline 1 & & 5 & 5 & 4 & 5 & 5 & 5 & 5 & 5 & 5 & 5 & 49 & $98,010 \%$ & Sangat Ba: \\
\hline 2 & & 5 & 5 & 4 & 5 & 4 & 4 & 4 & 4 & 5 & 4 & 44 & $88,0,1 \%$ & Bax \\
\hline 3 & & 4 & 4 & 4 & 5 & 4 & 4 & 4 & 4 & 4 & 4 & 41 & $82,11 \%$ & Bax \\
\hline
\end{tabular}

Persentase $=-----$

268

Persentase $=------$

3

Persentase $=89,33 \%$

Keterangan:

$\mathrm{F}=$ Jumlah persentase keseluruhan subjek
$\mathrm{N}$ = banyaknya subjek

2) Uji Coba Kelompok Kecil

Dalam uji coba kelompok kecil peneliti menyebarkan angket kepada 6 orang mahasiswa yang mewakili karakteristik mahasiswa yang berkemampuan baik, sedang/menengah, dan yang berkemampuan rendah. Angket respon mahasiswa ini terdiri dari 10 pernyataan yang terdiri dari 8 butir pernyataan positif yaitu butir 2, 3, 4, 6, 7, 8, 9, 10 dan sebanyak 2 butir pernyataan negatif yaitu butir 1 dan 6 . Hasil data kuantitatif dari uji coba kelompok kecil selengkapnya dapat dilihat pada Tabel III dan Tabel IV berikut ini.

Tabel III. Angket Dalam Uji Coba Kelompok Kecil

\begin{tabular}{|c|l|c|c|c|c|c|c|c|c|c|c|}
\hline \multirow{2}{*}{ No } & \multirow{3}{*}{ Responden } & \multicolumn{10}{|c|}{ Nomor Butir } \\
\cline { 3 - 12 } & & $\mathbf{1}$ & $\mathbf{2}$ & $\mathbf{3}$ & $\mathbf{4}$ & $\mathbf{5}$ & $\mathbf{6}$ & $\mathbf{7}$ & $\mathbf{8}$ & $\mathbf{9}$ & $\mathbf{1 0}$ \\
\hline 1 & I & TS & C & S & S & C & KS & S & S & SS & SS \\
\hline 2 & II & KS & S & S & S & S & KS & C & S & SS & S \\
\hline 3 & III & TS & SS & S & SS & S & TS & S & S & SS & S \\
\hline 4 & IV & TS & S & SS & SS & S & KS & S & SS & S & SS \\
\hline 5 & V & TS & SS & S & SS & S & TS & S & SS & S & SS \\
\hline 6 & VI & TS & SS & S & SS & S & TS & S & S & SS & S \\
\hline
\end{tabular}

Tabel IV. Angket Dalam Uji Coba Kelompok Kecil Dikali Bobot Tiap Pilihan

\begin{tabular}{|c|c|c|c|c|c|c|c|c|c|c|c|c|c|c|}
\hline \multirow{2}{*}{$\mathrm{N}_{0}$} & \multirow{2}{*}{ Responden } & \multicolumn{9}{|c|}{ Jawaban x Bobot Tiap Pilihan } & \multirow{2}{*}{\multicolumn{2}{|c|}{ Jumlah }} & \multirow{2}{*}{ Prosentase } & \multirow{2}{*}{ Kriteria } \\
\hline & & 1 & 2 & 3 & 4 & & & & 8 & & & & & \\
\hline $1 \mathrm{I}$ & & 5 & 3 & 4 & 4 & $\mathrm{y}$ & & & 4 & 5 & 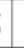 & 41 & $82,00 \%$ & Baik \\
\hline $2 \mathrm{I}$ & & 4 & 4 & 4 & 4 & 4 & & & 4 & 5 & . & 40 & $80,00 \%$ & Baik \\
\hline 31 & & 5 & 5 & 4 & 5 & 4 & & $t$ & 4 & J & 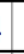 & 45 & $90,00 \%$ & Sangat Baik \\
\hline 4 & IV & 5 & 4 & 2 & 5 & 4 & & $t$ & 5 & 4 & 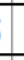 & 45 & $90,00 \%$ & Sangat Baik \\
\hline 5 & & 5 & 5 & 4 & 5 & 4 & & + & & 4 & 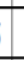 & 46 & $92,00 \%$ & Sangat Baik \\
\hline 61 & & 5 & 5 & 4 & 2 & 4 & 5 & $t$ & 4 & y & 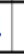 & 45 & $90,00 \%$ & Sangat Baik \\
\hline
\end{tabular}

$\mathrm{F}$

Persentase $=----$

524

Persentase $=-------$

6

Prosentase $=87,33 \%$

Keterangan:

$\mathrm{F}=$ Jumlah prosentase keseluruhan subjek

$\mathrm{N}$ = banyaknya subjek

\section{3) Uji Coba Lapangan}

Dalam uji coba lapangan peneliti menyebarkan angket kepada 20 orang mahasiswa semester IV jurusan Pendidikan Teknik Informatika, Universitas Pendidikan Ganesha yang sebelumnya telah mengambil matakuliah Kurikulum dan Pengajaran pada semester III. Angket respon mahasiswa ini terdiri dari 10 pernyataan yang terdiri dari 8 butir pernyataan positif yaitu butir 2, 3, 4, 5, 7, 8, 9, 10 dan sebanyak 2 butir pernyataan negatif yaitu butir 1 dan 6 . Hasil data kuantitatif 
dari uji coba lapangan selengkapnya dapat dilihat pada Tabel V dan Tabel VI.

Tabel V. Angket Dalam Uji Coba Lapangan

\begin{tabular}{|c|c|c|c|c|c|c|c|c|c|c|c|}
\hline \multirow{2}{*}{ No } & \multirow{2}{*}{ Responden } & \multicolumn{10}{|c|}{ Nenor Batir } \\
\hline & & 1 & 2 & 3 & 4 & 5 & 6 & 7 & 8 & 9 & 10 \\
\hline 1 & & KS & s & ss & S & S & TS & C & $\mathbf{s}$ & S & ss \\
\hline 2 & II & KS & $s$ & $\mathbf{s}$ & SS & $S$ & KS & $\mathrm{C}$ & $\mathbf{S}$ & SS & Ss \\
\hline 3 & III & TS & $\mathbf{s s}$ & $\mathbf{s}$ & SS & S & TS & $\mathbf{S}$ & $\mathbf{s}$ & SS & $\mathrm{s}$ \\
\hline 4 & $\mathrm{~N}$ & KS & $s$ & Ss & S & SS & KS & ss & Ss & $\mathrm{S}$ & $\mathrm{s}$ \\
\hline 5 & $\mathrm{~V}$ & TS & $\mathbf{s s}$ & $\mathbf{s}$ & SS & $S$ & TS & $\mathrm{s}$ & $\mathbf{s}$ & SS & Ss \\
\hline 6 & $\mathrm{yI}$ & TS & $\mathbf{s s}$ & Ss & $\mathrm{s}$ & $S$ & TS & $\mathrm{s}$ & $\mathbf{s}$ & SS & $\mathrm{s}$ \\
\hline 7 & VII & KS & $s$ & s & S & c & KS & s & ss & SS & $\mathrm{s}$ \\
\hline 8 & VIII & KS & $\mathbf{s s}$ & ss & SS & S & KS & S & $\mathbf{s}$ & S & Ss \\
\hline 9 & $\mathrm{IX}$ & TS & $\mathbf{s s}$ & S & SS & SS & TS & C & $\mathbf{s}$ & SS & SS \\
\hline 10 & $\mathrm{X}$ & TS & $s$ & ss & S & c & IS & S & ss & Ss & ss \\
\hline 11 & XI & TS & $s$ & ss & SS & $S$ & TS & C & Ss & $S$ & $\mathrm{~s}$ \\
\hline 12 & XII & KS & $s$ & Ss & SS & c & KS & SS & ss & SS & S \\
\hline 13 & XIII & KS & $s$ & S & SS & c & KS & SS & $\mathbf{s}$ & S & S \\
\hline 14 & $\mathrm{XIV}$ & TS & s & $\mathbf{s}$ & S & S & IS & C & $\mathbf{s}$ & SS & Ss \\
\hline 15 & XV & KS & $\mathbf{s s}$ & $\mathrm{s}$ & S & SS & KS & $\mathbf{S}$ & $\mathbf{s}$ & SS & S \\
\hline 16 & $\mathrm{xy}$ & TS & $\mathbf{s s}$ & $\mathrm{S}$ & SS & $\mathrm{S}$ & KS & is & $\mathbf{s}$ & $\mathrm{S}$ & SS \\
\hline 17 & XVI & TS & $\mathbf{s s}$ & Ss & S & c & TS & $\mathbf{S}$ & Ss & S & ss \\
\hline 18 & XVIII & KS & $s$ & $\mathrm{~S}$ & SS & SS & TS & SS & Ss & SS & SS \\
\hline 19 & $\mathrm{XIX}$ & KS & $\mathbf{S S}$ & $\mathrm{S}$ & S & S & KS & $\mathbf{S}$ & Ss & SS & S \\
\hline 20 & $\mathrm{Xx}$ & TS & $\mathbf{s s}$ & Ss & S & SS & TS & SS & $\mathbf{s}$ & SS & S \\
\hline
\end{tabular}

Tabel VI. Angket Dalam Uji Coba Lapangan Dikali Bobot Tiap

Pilihan

\begin{tabular}{|c|c|c|c|c|c|c|c|c|c|c|c|c|c|c|c|}
\hline \multirow{2}{*}{ No } & \multirow{2}{*}{\multicolumn{2}{|c|}{ Respenda }} & \multicolumn{10}{|c|}{ Jnohen I Bobet Tipp Fitivn } & \multirow{2}{*}{ Julal } & \multirow{2}{*}{ Prosentuse } & \multirow{2}{*}{ Kritarin } \\
\hline & & & 1 & 2 & 3 & & 5 & 6 & 7 & 8 & , & 10 & & & \\
\hline 1 & I & & 1 & 4 & 5 & 4 & 4 & 5 & 3 & 4 & 4 & 5 & 42 & $8, \omega \%$ & Bot \\
\hline 2 & II & & 1 & 4 & 4 & 5 & 4 & 4 & 3 & 4 & 5 & 5 & 42 & $8,0 \%$ & Bgz \\
\hline 3 & III & & 5 & 5 & $4:$ & 5 & 4 & 5 & 4 & 4 & 5 & 4 & 45 & $90, \mathbf{w \%}$ & Sangt Bik \\
\hline 4 & IV & & 1 & 4 & 5 & 4 & 5 & 4 & 5 & 5 & 4 & 4 & 44 & $8 \%, 10 \%$ & Bot \\
\hline 5 & $\mathrm{v}$ & & 5 & 5 & $4:$ & 5 & 4 & 5 & 4 & 4 & 5 & 5 & 46 & 92,w\% & Sangt Bik \\
\hline 6 & v & & 5 & 5 & 5 & 4 & 4 & 5 & 4 & 4 & 5 & 4 & 45 & $90,0 \%$ & Sangatkik \\
\hline 7 & VI & & 1 & 4 & 4 & 4 & 3 & 4 & 4 & 5 & 5 & 4 & 41 & $82,0 \%$ & Bat \\
\hline 8 & VII & & 1 & 5 & 5 & 5 & 4 & 4 & 4 & 4 & 4 & 5 & 44 & $8 \%$ & Bot \\
\hline 9 & IX & & 5 & 5 & $4:$ & 5 & 5 & 5 & 3 & 4 & 5 & 5 & 46 & 92,0\% & SangatBik \\
\hline 10 & $\mathrm{x}$ & & 5 & 4 & 5 & 4 & 3 & 5 & 4 & 5 & 5 & 5 & 45 & $90,6 \%$ & Sangat Bik \\
\hline 11 & XI & & 5 & 4 & 5 & 5 & 4 & 5 & 3 & 5 & 4 & 4 & 44 & $88,6 \%$ & Bot \\
\hline 12 & XII & & 1 & 4 & 5 & 5 & 3 & 4 & 5 & 5 & 5 & 4 & 44 & $88,6 \%$ & Bot \\
\hline 13 & XIII & & 1 & 4 & 4 & 5 & 3 & 4 & 5 & 4 & 4 & 4 & 41 & $82,10 \%$ & Bat \\
\hline 14 & IV & & 5 & 4 & 4 & 4 & 4 & 5 & 3 & 4 & 5 & 5 & 43 & $85,6 \%$ & Bat \\
\hline 15 & $\mathrm{XV}$ & & 1 & 5 & 4 & 4 & 5 & 4 & 4 & 4 & 5 & 4 & 43 & $8,6 \%$ & Baz \\
\hline 16 & $\mathrm{XY}$ & & 5 & 5 & 4 & 5 & 4 & 4 & 5 & 4 & 4 & 5 & 45 & $90,0 \%$ & Sangat Bik \\
\hline 17 & XVI & & 5 & 5 & 5 & 4 & 3 & 5 & 4 & 5 & 4 & 5 & 45 & 90,0\% & Sangt Bik \\
\hline 18 & XYII & & 1 & 4 & 4 & 5 & 5 & 5 & 5 & 5 & 5 & 5 & 47 & $9,0 \%$ & Sangat Bik \\
\hline 19 & XIX & & 1 & 5 & 4 & 4 & 4 & 4 & 4 & 5 & 5 & 4 & 43 & $85,6 \%$ & Bat \\
\hline 20 & $x x$ & & 5 & 5 & 5 & 4 & 5 & 5 & 5 & 4 & 5 & 4 & 47 & M, W\% & Sangat Bik \\
\hline
\end{tabular}

F

Persentase $=---$

1.764

Persentase $=------$

Persentase $=88,20 \%$

Keterangan:

$\mathrm{F}=$ Jumlah persentase keseluruhan subjek

$\mathrm{N}$ = banyaknya subjek

\section{e. Maintenance}

Pemeliharaan suatu perangkat lunak sangat diperlukan, termasuk di dalamnya adalah pengembangan lebih lanjut, karena perangkat lunak yang dibuat sekarang tidak akan selamanya hanya beroperasi seperti itu saja. Pengembangan diperlukan ketika adanya perubahan yang disesuaikan dengan permintaan/kebutuhan pengguna perangkat lunak tersebut.

8. Designing and Conducting Formative Evaluation

Setelah menyelesaikan langkah menyeleksi dan mengembangkan media pembelajaran, langkah berikutnya yaitu melaksanakan evaluasi formatif. Evaluasi formatif dilakukan untuk memperoleh data guna merevisi media pembelajaran yang dihasilkan agar lebih efektif dan berkualitas.

\section{Revising Instruction}

Langkah terakhir yaitu merevisi media pembelajaran yang telah diuji. Adapun solusi yang diberikan untuk masingmasing kendala yang ditemukan dalam media pembelajaran berbasis web untuk mata kuliah Kurikulum dan Pengajaran, antara lain sebagai berikut.

a) Belum tersedianya fasilitas upload soal quiz yang menggunakan format excel

Untuk mengatasi permasalahan ini, maka dibuatlah sebuah form yang memudahkan dosen untuk mengupload soal quiz. Adapun bentuk tampilan formnya dapat dilihat pada gambar berikut.

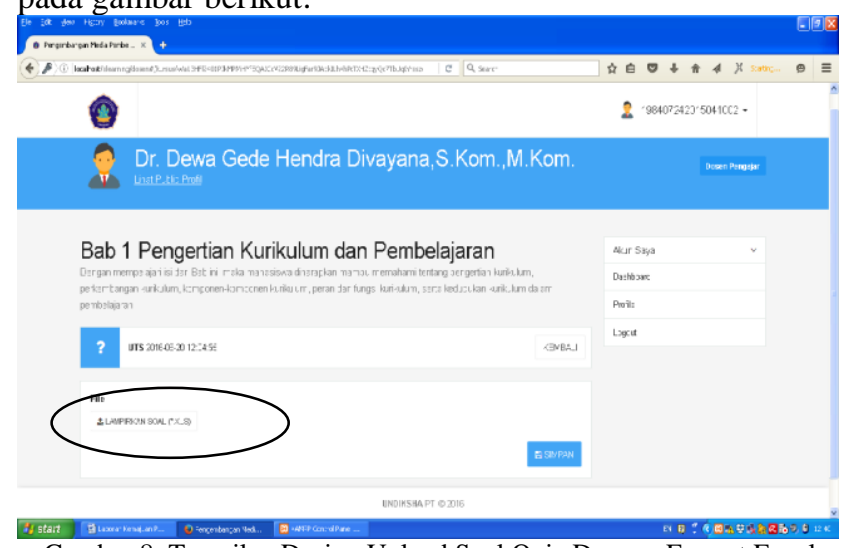

Gambar 8. Tampilan Design Upload Soal Quiz Dengan Format Excel 
b) Belum tersedianya fasilitas untuk mensetting waktu pelaksanaan quiz, sehingga proses penyimpanan hasil penilaian dapat diotomatisasi

Untuk mengatasi permasalahan ini, maka dibuatlah sebuah form yang memudahkan dosen untuk mengatur waktu/ambang batas penyelesaian quiz secara otomatis, sehingga proses penyimpanan hasil penilaian dapat berjalan secara otomatis. Adapun bentuk tampilan formnya dapat dilihat pada gambar berikut.

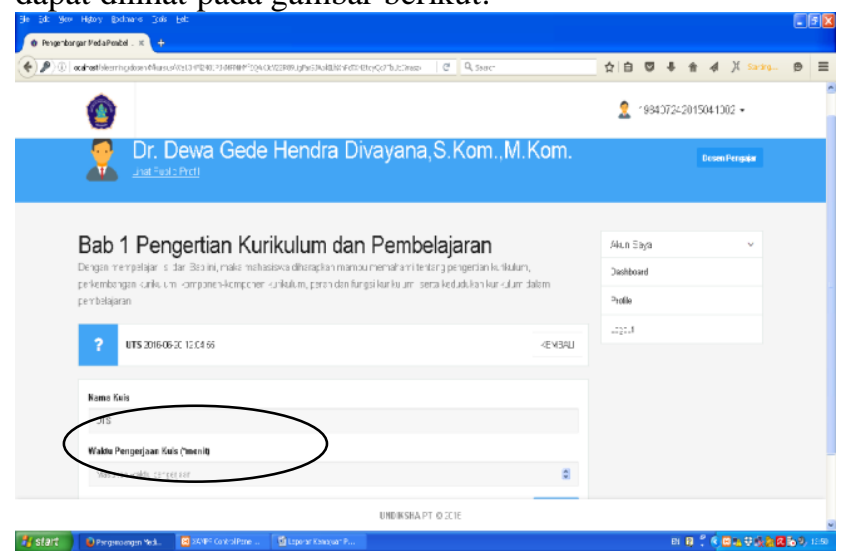

Gambar 9. Tampilan Design Setting Waktu Pengerjaan Quiz

c) Belum tersedianya menu utama

Untuk mengatasi permasalahan ini, maka dibuatlah sebuah form halaman utama. Adapun bentuk tampilan formnya dapat dilihat pada gambar berikut.

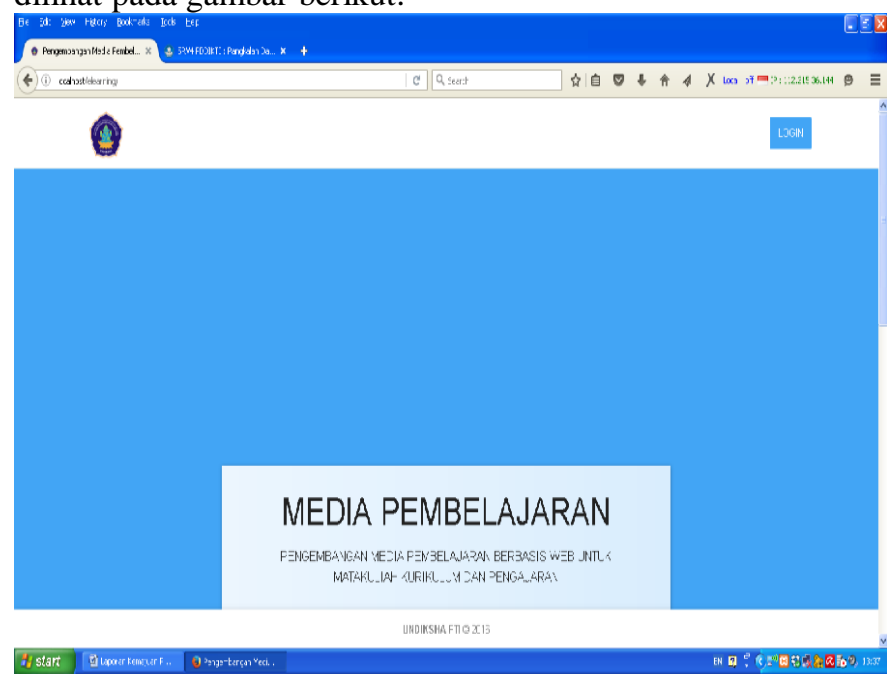

Gambar 10. Tampilan Menu Utama

d) Belum tersedianya fasilitas untuk mengganti/mengubah username dan password

Untuk mengatasi permasalahan ini, maka dibuatlah sebuah form untuk mengubah username dan password. Adapun bentuk tampilan formnya dapat dilihat pada gambar berikut.
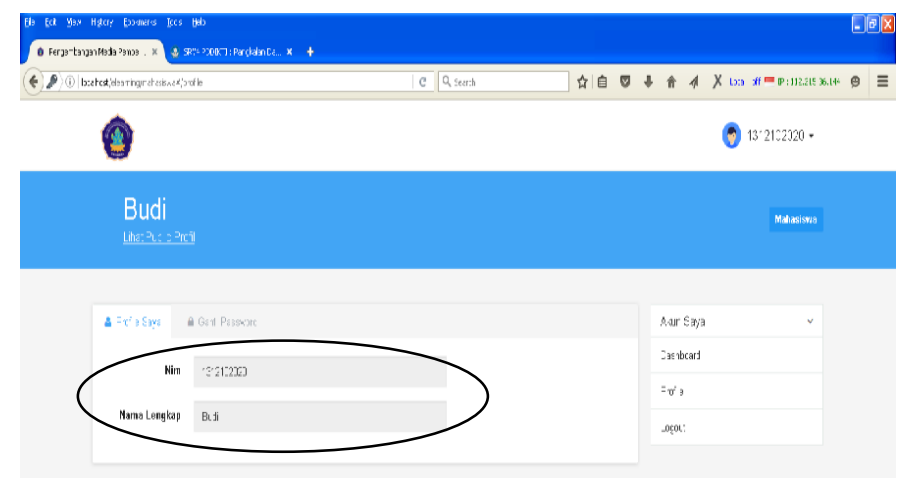

Gambar 11. Tampilan Form Ubah Username dan Password

e) Belum tersedianya fasilitas untuk dapat melihat seluruh materi yang ada

Masalah ini ditemukan pada saat uji coba perorangan, uji coba kelompok kecil, dan uji coba lapangan terhadap kelayakan isi dan media dari media pembelajaran berbasis web untuk mata kuliah Kurikulum dan Pengajaran. Untuk mengatasi permasalahan ini, maka dibuatlah sebuah form untuk dapat menampilkan semua isi materi (semua bab) sehingga tidak terpisah-pisah dalam halaman web yang berbeda-beda. Adapun bentuk tampilan formnya dapat dilihat pada gambar berikut.

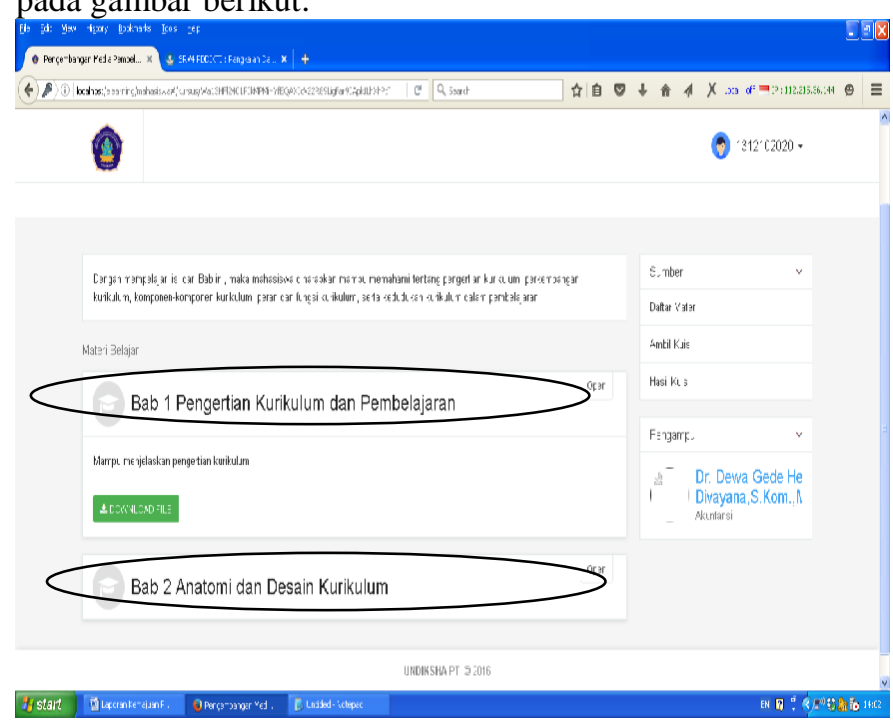

Gambar 12. Tampilan Form Melihat Semua Mater

\section{B. Pembahasan}

Berdasarkan hasil penelitian yang telah dijelaskan sebelumnya, maka ada beberapa hal yang akan peneliti bahas lebih dalam tentang hasil penelitian ini antara lain sebagai berikut.

1. Uji Coba Perorangan 
Pada uji coba perorangan terhadap media pembelajaran berbasis web untuk mata kuliah Kurikulum dan Pengajaran diperoleh hasil persentase sebesar 89,33\%. Hal ini bermakna bahwa aspek kelayakan isi dan aspek kelayakan media termasuk ke dalam kriteria baik, sehingga tidak perlu dilakukan revisi lagi secara menyeluruh, akan tetapi hanya sebatas perbaikan berupa penambahan fasilitas menu utama, penyimpanan nilai quiz serta fasilitas untuk mengubah username dan password.

\section{Uji Coba Kelompok Kecil}

Pada uji coba kelompok kecil terhadap media pembelajaran berbasis web untuk mata kuliah Kurikulum dan Pengajaran diperoleh hasil persentase sebesar 87,33\%. Hal ini bermakna bahwa aspek kelayakan isi dan aspek kelayakan media termasuk ke dalam kriteria baik, sehingga tidak perlu dilakukan revisi lagi secara menyeluruh, akan tetapi hanya sebatas perbaikan berupa penambahan fasilitas menu utama, menampilkan seluruh materi dalam satu halaman web, serta fasilitas untuk mengubah username dan password.

\section{Uji Coba Lapangan}

Pada uji coba lapangan terhadap media pembelajaran berbasis web untuk mata kuliah Kurikulum dan Pengajaran diperoleh hasil persentase sebesar $88,20 \%$. Hal ini bermakna bahwa aspek kelayakan isi dan aspek kelayakan media termasuk ke dalam kriteria baik, sehingga tidak perlu dilakukan revisi lagi secara menyeluruh, akan tetapi hanya sebatas perbaikan berupa penambahan fasilitas menu utama, menampilkan seluruh materi dalam satu halaman web, pengaturan waktu mengerjakan quiz dan penyimpanan hasil secara otomatis, serta fasilitas untuk mengubah username dan password.

\section{KESIMPULAN DAN SARAN}

\section{A. Kesimpulan}

Berdasarkan hasil penelitian dan pembahasan sebelumnya, maka dapat ditarik beberapa kesimpulan antara lain:

a. Media pembelajaran berbasis web untuk mata kuliah Kurikulum dan Pengajaran yang diterapkan di jurusan Pendidikan Teknik Informatika dapat memudahkan dosen dalam mentransfer materi yang diajarkan kepada mahasiswa, karena materi kuliah sudah dapat mudah diakses oleh mahasiswa.

b. Media pembelajaran berbasis web untuk mata kuliah Kurikulum dan Pengajaran yang diterapkan di jurusan Pendidikan Teknik Informatika dapat melatih kemampuan dan keaktifan mahasiswa, karena mahasiswa dapat belajar sendiri kapanpun dan dimanapun mereka berada.

\section{B. Saran}

Berdasarkan kesimpulan yang disampaikan di atas, maka penulis memberikan beberapa saran, antara lain:

a. Media pembelajaran berbasis web ini hendaknya dapat dimanfaatkan sebaik-baiknya oleh dosen pengampu mata kuliah Kurikulum dan Pengajaran dan mahasiswa sebagai salah satu media pembelajaran yang dapat digunakan untuk menunjang proses belajar mengajar.

b. Media pembelajaran berbasis web ini hendaknya bisa digunakan sebagai contoh untuk pengembangan media pembelajaran dalam bentuk lainnya dan dengan materi yang berbeda.

\section{DAFTAR PUSTAKA}

[1] R. Amalia, N. Ambarsari N, dan M. Wiyogo. Membangun Media Pembelajaran Interaktif Berbasis Web Untuk Anak Bergaya Belajar Visual Tingkat Sekolah Dasar. Surabaya : SESINDO, 2014.

[2] R. Darmawan, "Pengembangan Model Media Pembelajaran Berbasis Komputer untuk Pendidikan Desain," Seminar Nasional Aplikasi Teknologi Informasi 2006, pp. 51-56, Juni 2006.

[3] I.G.M. Darmawiguna, dan M.W.A. Kesiman, "Media Pembelajaran Berbasis Web dan Flash Untuk Mata Kuliah Riset Operasi di Jurusan PTI, Undiksha, ” Jurnal Sains \& Teknologi, Vol 2, No. 1, pp. 128-138, April 2013.

[4] I.J. Dewanto. Web Desain (Metode Aplikasi dan Implementasi) Yogyakarta: Graha Ilmu, 2006.

[5] Heinich dan Molenda. "Jenis-jenis Media pembelajaran", 2005 Tersedia pada http://staff.uny.ac.id/sites/default/files/pendidikan/ Dr.\%20Sujarwo,\%20M.Pd./Materi\%20II\%20media.doc. (Diakses pada 15 Oktober 2015).

[6] I.W. Kertih. Model Pembelajaran Inovatif Dalam Pendidikan IPS Berbasis Kompetensi. Singaraja: Universitas Pendidikan Ganesha, 2006.

[7] W. Lasmawan. Inovasi Pendidikan IPS. Singaraja : IKIP Negeri Singaraja, 2002.

[8] W. Lasmawan. Paradigma Baru Pengorganisasian Materi dan Model Pembelajaran Inovatif PKn Berbasis Kurikulum Tingkat Satuan Pendidikan (Sebuah Tawaran Konsep dan Aplikasi). Singaraja: Universitas Pendidikan Ganesha, 2006.

[9] I.W. Santyasa. Landasan Konseptual Media Pembelajaran. Disajikan dalam Workshop Media Pembelajaran bagi Guru-Guru SMA Negeri Banjar Angkan pada tanggal 10 Januari 2007 di Banjar Angkan Klungkung. Singaraja: Universitas Pendidikan Ganesha, 2007.

[10] I.W. Santyasa. Metode Penelitian Tindakan Kelas, Pengembangan, Korelasional, Kausal Komparatif, dan Eksperimen. Singaraja: Lembaga Penelitian Universitas Pendidikan Ganesha, 2009.

[11] I.M.G. Sunarya, "Pengembangan Anime (Animation Learning Media) Untuk Pembelajaran Komunikasi Data Bahasan Protokol dan Arsitektur Protokol," Jurnal Sains \& Teknologi, Vol 1, No. 1, pp. 1929, April 2012.

[12] Y. Suherman. Pengembangan Media Pembelajaran Bagi ABK, Diklat Profesi Guru PLB Wilayah X. Jawa Barat: Bumi Aksara, 2009.

[13] Peraturan Pemerintah Nomor 19 Tahun 2005 Tentang Standar Nasional Pendidikan. 